Volume 3 Nomor 1, Maret 2021, Halaman $61-70$.

\title{
Edukasi Tentang Pergaulan Remaja yang Sehat di Lingkungan Sekolah dan Keluarga SMK Muhammadiyah 4 Cileungsi
}

\author{
Siti Pangarsi Dyah Kusuma Wardani ${ }^{1)}$, Dina Martha Fitri' ${ }^{2)}$ \\ ${ }^{1,2)}$ Program Sarjana Terapan Kebidanan, STikes Mitra RIA Husada \\ Email: dani.midwife@gmail.com ${ }^{1}$, marthadina@ymail.com ${ }^{2}$
}

\begin{abstract}
Abstrak
Pada perkembangan zaman saat ini yang tampak jelas memang pergaulan negatif yang lebih mengarah kepada para remaja dalam bertingkah laku didalam kehidupan sosial. Dalam kehidupan sosial banyak kita lihat remaja berperilaku negatif dalam pergaulan, hal ini dikarenakan remaja mudah sekali terpengaruh oleh lingkungan khusus yang ada disekitarnya. Para remaja sudah mulai diberikan kepercayaan untuk memilih sendiri pergaulan yang baik maupun tidak baginya. Sehingga peran cara mendidik orang tua di rumah berpengaruh terhadap pembentukan karakter remaja, baik di lingkungan rumah, masyarakat, maupun sekolah. Pengaruh lingkungan pun sangat berperan dalam pembentukan perilaku remaja, karena remaja tak jarang banyak menghabiskan waktu di luar rumah setelah pulang sekolah. Dalam kehidupan sosial ada berbagai bentuk pergaulan, ada yang sehat ada pula yang dikategorikan pergaulan yang tidak sehat. Pelaksanaan kegiatan meliputi perencanaan, pelaksanaan, dan pelaporan. Pengambilan data dilakukan melalui observasi langsung. Hasil pengabdian ini adalah siswa dapat memahami bahwa edukasi pergaulan sehat dan menghindari kebiasaan tersebut merupakan hal yang sangat positif bagi kesehatan diri dan masa depan mereka. Kesimpulan kegiatan ini adalah Kegiatan Pengabdian kepada Masyarakat berjalan dengan baik dan lancar sesuai jadwal dan rencana dan siswa dapat memahami materi yang disampaikan terlihat dari beberapa pertanyaan yang diberikan. Saran adalah Perlu perhatian khusus mengenai pergaulan remaja melalui edukasi kesehatan.
\end{abstract}

Kata Kunci : Pergaulan, Remaja, Sosial, Lingkungan, Sehat

\begin{abstract}
Abtract
In the current development, what seems clear is that negative associations are more directed at adolescents in their behavior in social life. While positive interactions are rarely shown by teenagers in their social life, because teenagers are affected in their particular environment. Where adolescents must be able to choose and follow an association which he thinks is a good or positive one. In this case, the role of the people around them will also affect the association of teenagers, at home the role of parents helps shape children's character to be better, in school teachers also help shape student character. The environment is one of the causes of good or deviant adolescent interactions, because teenagers spend a lot of their time playing after school so automatically they interact more socially with the general environment. In social life, there are various forms of association, some are healthy, some are categorized as unhealthy associations. The implementation of activities includes
\end{abstract}


planning, implementation and reporting. Data were collected through direct observation. The result of this service is that students can understand that education on healthy relationships and avoiding these habits is very positive for their health and their future. The conclusion of this activity is that Community Service Activities run well and smoothly according to the schedule and plan and students can understand the material presented as seen from some of the questions given.

Keywords : Social, Environmental, Healthy

DOI: https://doi.org/10.31943/abdi.v3i1.32

\section{A. Pendahuluan}

Remaja mempunyai urgensi yang sangat penting dan vital dalam pembangunan dan perkembangan kehidupan manusia yang akan datang. Masa depan suatu negara ditentukan oleh bagaimana kualitas generasi muda yang akan datang. Masa remaja merupakan masa transisi pertumbuhan dan perkembangan seorang anak menuju ke arah dewasa. Tak jarang banyak terjadi gejolak dan masalah pada remaja, mereka memiliki semangat dan rasa ingin tahu yang besar, serta berusaha mencari jati diri menuju ke arah dewasa. Pergaulan bebas di kalangan remaja diidentikkan dengan pergaulan remaja yang menyimpang dan biasanya mengarah pada perbuatan seks. Pada era yang semakin maju semakin beragam pula tingkah laku remaja yang menyebabkan beberapa masalah sosial yang terjadi di masyarakat. Perkembangan teknologi pun juga dapat banyak memberi pengaruh buruk bagi remaja karena kurangnya edukasi yang diberikan kepada remaja sebagai filter. (Roy, 2011).

Yayah Khisbiyah, misalnya, mengutip hasil penelitian tentang angka kehamilan yang tidak diinginkan di kalangan remaja. Sebuah Lembaga konseling remaja, tahun 1990 menangani sekitar 80 kasus kehamilan di luar nikah pada remaja usia 14 - 24 tahun. Penelitian yang dilakukan oleh Warouw di Manado mendapatkan hasil sebanyak 472 (71,3\%) dari 663 sampel remaja yang diambil secara acak, mengalami kehamilan yang tidak diinginkan dan berusaha melakukan induksi haid. Dari jumlah tersebut, 291 responden (28,8\%) berusia 1419 tahun, 345 responden (52\%) berusia 20-24 tahun (Husniaty, E. Noor, 2016).

Kehidupan sehari-hari para remaja tidak terlepas dari pengaruh yang konstruktif dan pengaruh destruktif. Sebenarnya kedua sipat itu telah ada semenjak manusia (remaja) dilahirkan. 3 Sifat-sifat ini akan berpengaruh pada para remaja, tergantung dimana remaja itu berada. Jika remaja tersebut ada pada lingkungan 
yang tidak baik maka yang akan dominan adalah pola tingkah laku yang tidak baik. Demikian pula sebaliknya (Kartini Kartono, 2005).

Terjadinya pergaulan bebas di kalangan remaja pada umumnya bukan disebabkan pengetahuan melainkan oleh ketidaktahuan mereka dalam hal seks. Adapun yang menjadi faktor terjadinya pergaulan bebas adalah naluri seks yang tidak terkendali. Pemahaman ini menyimpulkan kecenderungan pergaulan bebas di kalangan remaja lebih dipegaruhi oleh dorongan nafsu seksual pada remaja yang sangat sulit untuk dikendalikan. Analisi situasi di SMK Muhammadiyah 4 Cileungsi tidak memiliki masalah yang signifikan dalam hal pergaulan bebas hanya saja disini kita wajib memberikan hal positif agar siswa memiliki masa depan yang baik dan pergaulan yang sehat. Sebuah penelitian pernah dilakukan di Pamekasan Madura yang mana hasil penelitian itu melaporkan tentang aksi sekolompok pelajar SMA yang melakukan aksi borong kondom di beberapa apotik. Aksi Borong Kondom tersebut tentu saja tidak hanya sebatas 'membeli' kondom saja. Kekhawatiran yang sangat mencolok adalah kelanjutan dari proses pembelian kondom itu sampai kepada perilaku seksual bebas yang kini marak terjadi pada remaja di kota-kota besar.

Pada tahun 2007 dan 2010 KOMNAS Perlindungan Anak dan BKKBN pada melakukan penelitian tentang perilaku seksual sebelum menikah pada remaja, menunjukan hasil kecenderungan peningkatan. Menurut riset yang dilakukan BKKBN remaja putri yang belum menikah di wilayah Jakarta, Bogor, Tangerang dan Bekasi mengaku sudah tidak perawan dan bahkan tidak sedikit mengalami kasus kehamilan di luar nikah.

Sarwono (2017) mengatakan masalah seksualitas pada remaja timbul karena pengaruh berbagai faktor, antara lain : (1) Pada masa remaja terjadi peningkatan hormonal yang menyebabkan meningkatnya hasrat seksual pada remaja, sehingga mereka membutuhkan penyaluran melalui tingkah laku seksual, (2) Penundaan usia perkawinan. Baik secara hukum maupun norma sosial, menyebabkan meningkatkan syarat ketika akan menikah baik pendidikan, pekerjaan, dan persiapan secara mental, (3) Larangan, (4) Kurangnya informasi tentang Seks, (5) Ketidaktahuan orang tua serta masih dianggapnya pembicaraan mengenai seks dengan anaknya sebagai pembicaraan yang tabu membuat anak segan untuk 
bertanya dan bercerita mengenai pendidikan seksual, sehingga akhirnya banyak yang mencari tahu sendiri, (6) Pergaulan yang makin bebas. Masalah yang terlihat di SMK Muhammadiyah 4 Cileungsi adalah kurang pengetahuan siswa mengenai kendali diri dalam pergaulan sesame teman dilingkungan sekolah antara laki-laki dan permpuan.

\section{B. Metode}

Kegiatan ini dilakukan di SMK Muhammadiyah 4 Cileungsi pada Tanggal 22 Mei 2019. Persiapan : persiapan awal membuat proposal mengenai kegiatan yang akan dilakukan, melakukan survey Lapangan di SMK Muhammadiyah 4 Cileungsi, mengirimkan surat ijin ke SMK Muhammadiyah 4 Cileungsi, serta menggali informasi yang dibutuhkan, Pada Tahap pelaksanaan : mengadakan penyuluhan, memberikan sosialisasi, membuat Laporan dan terakhir tahap evaluasi. Pelaksanaan kegiatan ini dilakukan dengan metode penyuluhan yang dilakukan dengan metode ceramah, dan dilakukan pretest dan posttest dengan diberikan pertanyaan untuk melihat peningkatan pengetahuan remaja tentang pengetahuan yang diberikan.

\section{Hasil dan Pembahasan}

Berdasarkan kegiatan ini dilakukan di SMK Muhammadiyah 4 Cileungsi pada Tanggal 22 Mei 2019. (1) Memberikan soal pretest kepada siswa dan memberikan waktu 20 menit untuk menjawab 10 pertanyaan mengenai pergaulan yang sehat, (2) Tim memberikan penyuluhan berbentuk power point dan menjelaskan kepada para remaja, dan (3) memberikan soal posttest kepada siswa dan memberikan waktu 20 menit untuk menjawab 20 pertanyaan mengenai pergaulan yang sehat.

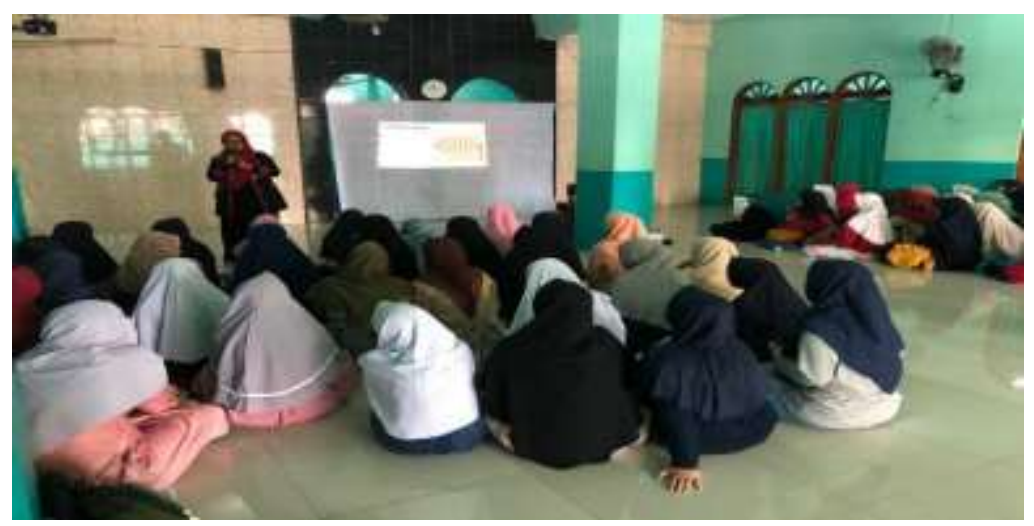

Gambar 1. Kegiatan Penyuluhan 
Pada gambar 1 dapat dilihat bahwa pembicara melakukan edukasi atau menyampaikan seluruh materi edukasi yang berkaitan dengan pergaulan remaja yang sehat di ruang aula SMK Muhammadiyah 4 Cileungsi.

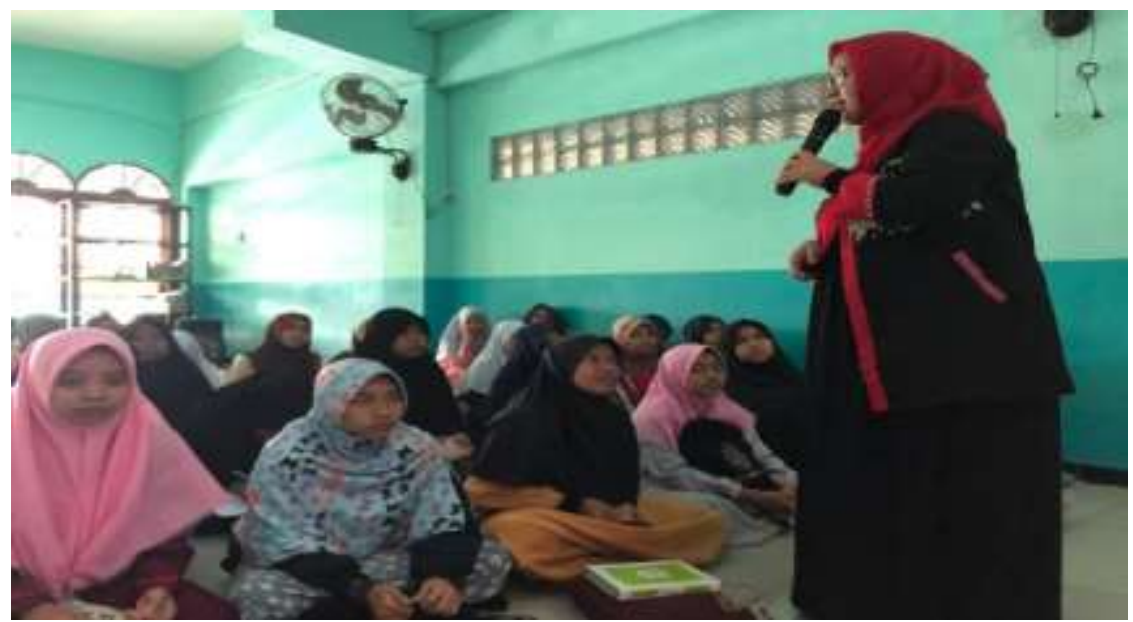

Gambar 2. Kegiatan Evaluasi Penyuluhan

Pada gambar 2 menjelaskan tentang kegiatan evaluasi penyuluhan yang sedang dilakukan oleh pembicara dengan cara memberikan pertanyaan secara langsung (tanya jawab) kepada peserta secara acak, juga mengisi soal post test. Hasil dari evaluasi tersebut seluruh pertanyaan secara langsung dapat terjawab oleh peserta dengan lancar, dan post test menunjukan peningkatan pengetahuan peserta.

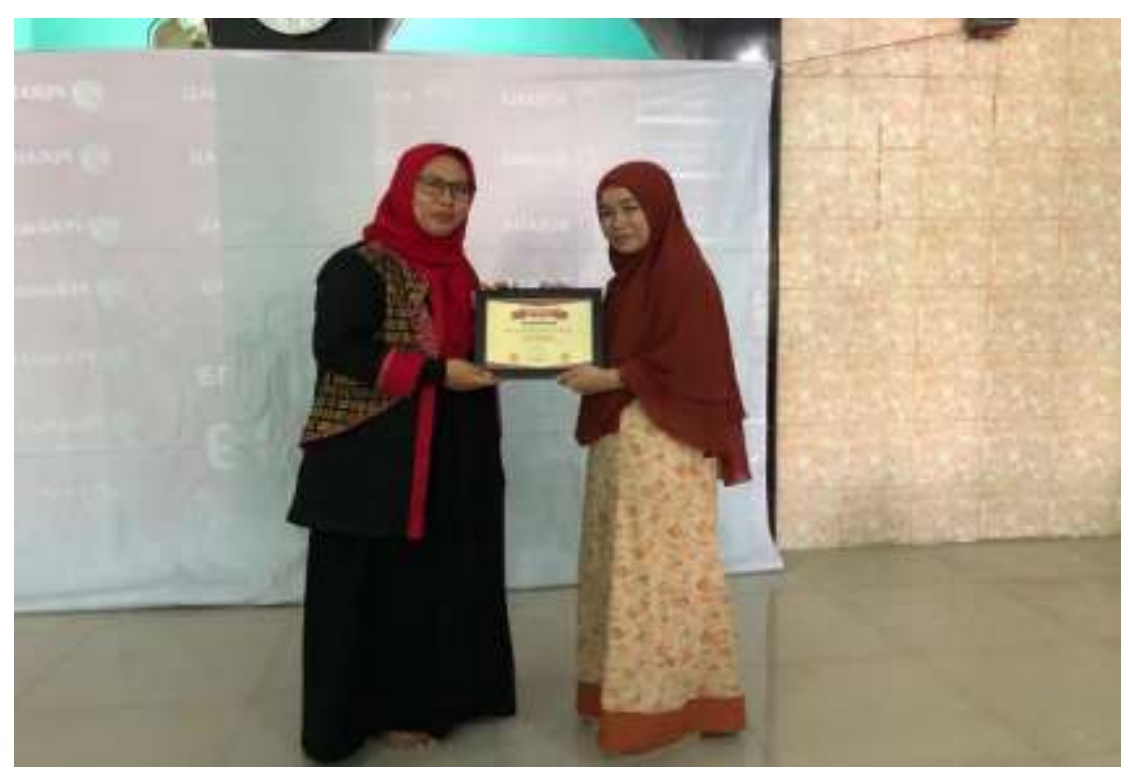

Gambar 3. Pemberian Piagam 


\section{ABDI WIRALODRA}

JURNAL PENGABDIAN KEPADA MASYARAKAT
ISSN 2656-5501 (Print)

ISSN 2714-8041 (Online)

Gambar 3 adalah gambar saat penyerahan piagam sebagai cinderamata dari pihak

SMK Muhammadiyah 4 Cileungsi kepada pembicara yang diserahkan oleh wakil kepala sekolah.

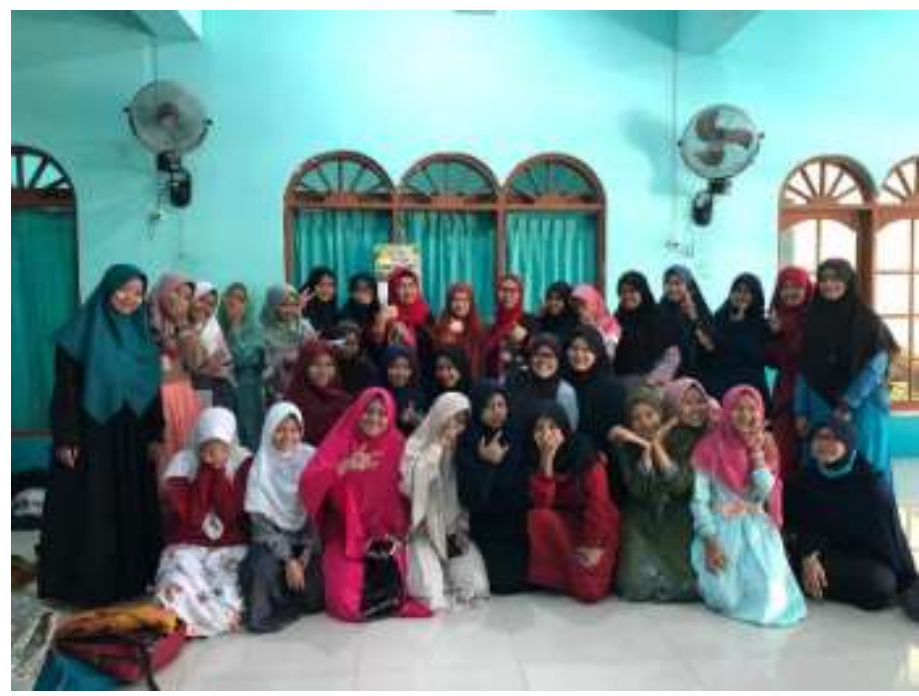

Gambar 4. Foto bersama Tim

Gambar 4 merupakan gambar tim pengabdian dan partisipan yang terdiri dari para pembicara Dina Martha Fitri dan Siti Pangarsi Dyah Kusuma Wardani, Wakil kepala sekolah SMK Muhammadiyah 4 Cileungsi dan para peserta, dengan peserta berjumlah 45 orang yang dilaksanakan di Aula SMK Muhammadiyah 4 Cileungsi.

Tabel 1. Hasil Pretest dan Postes

\begin{tabular}{lcccccc}
\hline \multirow{2}{*}{ Komponen } & \multicolumn{5}{c}{ Hasil Test } \\
& \multicolumn{2}{c}{ Jumlah } & $\%$ & Jumlah & \% \\
\hline Pengetahuan & Benar 10 & 0 & 0 & Benar 10 & 27 & 60 \\
Program & Benar 9 & 5 & 11,1 & Benar 9 & 15 & 33.3 \\
Pencegahan & Benar 8 & 8 & 17,7 & Benar 8 & 3 & 6,7 \\
Kekerasan Seksual & Benar 7 & 13 & 29 & Benar 7 & 0 & 0 \\
pada Anak dengan & Benar 6 & 19 & 42,2 & Benar 6 & 0 & 0 \\
Media Pembelajaran & Benar 5 & 0 & 0 & Benar 5 & 0 & 0 \\
& Benar 4 & 0 & 0 & Benar 4 & 0 & 0 \\
& Benar 3 & 0 & 0 & Benar 3 & 0 & 0 \\
& Benar 2 & 0 & 0 & Benar 2 & 0 & 0 \\
& Benar 1 & 0 & 0 & Benar 1 & 0 & 0 \\
\hline
\end{tabular}


Tabel 1, di atas adalah hasil pretest dan posttest pengetahuan remaja tentang pergaulan remaja yang sehat di lingkungan sekolah dan keluarga. Tabel di atas menjelaskan tentang adanya peningkatan persentase jumlah peserta yang menjawab benar pada 10 pertanyaan yang diajukan, artinya terjadi peningkatan pengetahuan peserta setelah diberikan edukasi.

Hasil kegiatan pengabdian masyarakat ini adalah (1) siswa dapat memahami bahwa edukasi pergaulan sehat dan menghindari kebiasaan merokok merupakan hal yang sangat positif bagi kesehatan diri dan masa depan mereka (2) kegiatan ini berjalan dengan lancar dengan jumlah peserta 45 orang siswa beserta para guru. Dari tabel diatas terlihat peningkatan pengetahuan setelah diberikan penyuluhan yaitu peningkatanya $90 \%$ dari sebelumnya yaitu 50\% hal tersebut akibat dari intervensi penyuluhan yang diberikan yang dimana remaja belum tahu mengenai pergaulan yang sehat menjadi tahu dan memahami. hal ini sejalan dengan Notoatmodjo yang menjelaskan pengetahuan adalah suatu kondisi pemahaman seseorang setelah melakukan pengamatan terhadap suatu objek tertentu. Pengamatan menggunakan panca indra manusia, yaitu indra penglihatan, pendengaran, penciuman, rasa dan raba. manusia dapat memperoleh pengetahuan lebih banyak melalui indra penglihatan dan pendengaran (Notoatmodjo, 2007).

Senada dengan hasil penelitian Agustini (2013), mengenai pelayanan kesehatan peduli remaja di tingkat puskesmas berperan penting dalam mewujudkan remaja sehat. Berdasarkan hal diatas bahwa Upaya pemerintah dalam mewujudkan remaja sehat, salah satunya melalui pembentukan ProgramPelayanan Kesehatan Peduli Remaja (PKPR). Remaja diberikan pelayanan khusus yang disesuaikandengan keinginan, selera, dan kebutuhannya.

Sama halnya dengan penelitian Rochayati (2015) yaitu Faktor-Faktor Yang mempengaruhi Perilaku Merokok Remaja di Sekolah Menengah Kejuruan Kabupaten Kuningan, hasil penelitiaannya sejalan denga pelaksanaan pengabdian kepada masyarakat yaitu remaja yang berperilaku merokok berat sebanyak 246 orang $(70,89 \%)$ dan 101 orang $(29,11 \%)$ berperilaku merokok ringan. Hal ini membuktikan masih ada prilaku merokok dikalangan remaja yang berdampak pergaulan yang tidak sehat. Senada juga dengan hasil penelitian Ayu Chitra Dewi, M. Turhan Yani (2014) mendapatkan hasil penelitian sebesar 51,6\% peran keluarga 
ABDI WIRALODRA

JURNAL PENGABDIAN KEPADA MASYARAKAT
ISSN 2656-5501 (Print)

ISSN 2714-8041 (Online)

masuk kategori cukup. Sehingga perilaku positif akan coba dikembangkan di lingkungan rumah, dan masyarakat. Kemudian hasil yang lain menunjukkan sebesar 50,22\% perilaku positif remaja masuk kategori cukup tinggi, serta peran kendali keluarga masuk dalam kategori tinggi.

Hasil pengabdian masyarakat menunjukkan setelah penyuluhan, para orang tua khususnya ibu-ibu menjadi lebih mengerti akan kenakalan-kenakalan remaja dan penanganannya. (Lingga, 2018). Sejalan dengan pengabdian masyarakat tersebut tersebut, penelitian yang dilakukan oleh Dadan Sumara (2017) juga menyebutkan Faktor yang melatar belakangi terjadinya kenakalan remaja dapat dikelompokkan menjadi faktor internal dan faktor eksternal. Faktor internal berupa krisis identitas dan kontrol diri yang lemah. Sedangkan kurangnya perhatian dari orang tua, kurangnya pemahaman agama, pengaruh lingkungan dan pengaruh teman sebaya, kualitas pendidikan serta masukknya pengaruh moderenisasi budaya barat sebagai faktor eksternal . Berdasarkan hasil pengabdian kepada masyarakat tersebut dapat kita pahami bersama bahwa peran orang tua juga mempengaruhi pergaulan remaja.

\section{Kesimpulan}

Kegiatan Pengabdian kepada Masyarakat berjalan dengan baik dan lancar sesuai jadwal dan rencana dan siswa dapat memahami materi yang disampaikan terlihat dari beberapa pertanyaan yang diberikan. Merokok merupakan suatu kebiasaan yang merugikan bagi kesehatan dan jembatan ke penyalahgunaan napza. Hal ini sangat merugikan generasi muda kedepannya sehingga kita harus memberikan sosialisasi yang terus menerus, karena perilaku menyimpang pada remaja lambat laun semakin meningkat dan terkadang dianggap masyarakat sebagai kenakalan remaja yang wajar dilakukan. Hal ini banyak kita temui di kehidupan sehari-hari seperti di lingkungan rumah, kendaraan umum, taman-taman kota, bahkan di wilayah sekolahan. Saran : 1) Sekolah memiliki agenda dalam memberikan edukasi kepada siswa terkait kesehatan diri maupun kespro. 2) Siswa harus memiliki motivasi dalam menjaga kesehatan diri dan mengikuti kegiatan sekolah.

3) Melakukan penyuluh secara terprogram mengenai pergaulan yang sehat pada remaja. 


\section{E. Ucapan Terima kasih}

Ucapan terima kasih kepada Ketua STIKes Mitra RIA Husada yang telah memfasilitasi kegiatan ini dan telah berkerjasama dengan Universitas Wiralodra. Terima kasih juga atas ijin yang diberikan oleh SMK Muhammadiyah 4 Cileungsi.

Serta mengucapkan banyak terima kasih kepada Mahasiswa yang telah membantu kegiatan ini.

\section{Daftar Pustaka}

Agustin, (2013). Remaja Sehat Melalui Pelayanan Kesehatan Peduli Remaja Di Tingkat Puskesmas

Ahmad, (2013). Persepsi Remaja terhadap prilaku seks Pranikah, Volume 1. No. 1. https://ejournal.ps.fisip-unmul.ac.id/site/wpcontent/uploads/2013/03/Ahmad\%20Taufik\%20(03-15-13-03-32-41).pdf

Ati Siti Rochayati. (2015). Jurnal Keperawatan Soedirman (The Soedirman Journal of Nursing), Volume 10, No.1, Maret. http://jks.fikes.unsoed.ac.id/index.php/jks/article/view/587/326

Ayu Chitra Dewi, M. Turhan Yani. (2014). Jurnal Kajian Moral, Volume 2, No 2. https://jurnalmahasiswa.unesa.ac.id/index.php/jurnal-pendidikankewarganegaraa/article/view/7841.

BKKBN. (2017). Survei Demografi Dan Kesehatan : Kesehatan Reproduksi Remaja 2017. Badan Kependudukan Dan Keluarga Berencana Nasional, 1606. file:///E:/JURNAL RENY/Jurnal pendukung/Seks Bebas/LaporanSDKI 2017-Remaja.pdf.

Diana, A., Yuviska, I. A., Iqmy, L. O., \& Evayanti,Y. (2020). Penyuluhan tentang bahaya seks bebas mempengaruhi pengetahuan remaja. Kebidanan Malahayati, 6 (1), 99-103. http://ejurnalmalahayati.ac.id/index.php/kebidanan/article/view/1732.

Roy. (2011). Pemahaman Tentang Seks Kaitanya dengan Sikap Terhadap Hubungan Seks Pranikah. Skripsi. Fakultas Psikologi UMS.

Husniaty, E. Noor. (2016). Menjadi Remaja Kreatif dan Mandiri. Yogyakarta : Publisher.

Lingga.(2014). Pengenalan dan Pencegahan Kenakalan Remaja (Adult Delicuency) melalui Psikoedukasi Keluarga. Vol. 1 No. 1. https://jceh.org/index.php/JCEH/article/view/2/7.

Sumara, Dadan. (2017). Kenakalan Remaja dan Penanganannya, Bandung : Universitas Padjajaran.

Kartini Kartono, (2005). Patologi sosial, Jakarta : PT. Raja Grafindo Persada.

Sarwono, S. W. (2007). Psikologi Remaja. Jakarta: PT Raja Grafindo Persada.

Sarwono, Wirawan Sarlito, (2004). Psikologi Remaja. Jakarta : PT. Raja Grafindo Persada.

Sarwono, Wirawan Sarlito, (2010). Teori-teori Psikologi Sosial, Jakarta : PT. Raja Grafindo Persada.

Soetjiningsih, (2007). Tumbuh Kembang Remaja dan Permasalahannya. Cetakan kedua. Jakarta : CV. Sagung Seto 
Shochib, Moch, (2000). Pola Asuh Orang Tua dalam Membentuk Anak Mengembangkan Disiplin Diri. Jakarta : PT. Rineka Cipta

Yusuf Abdullah. (1990). Bahaya Pergaulan Bebas. Jakarta : Media Dakwah. 